\title{
Review \\ Cytolytic Perforin as an Adjuvant to Enhance the Immunogenicity of DNA Vaccines
}

\author{
Ashish C. Shrestha *(D), Danushka K. Wijesundara, Makutiro G. Masavuli, Zelalem A. Mekonnen, \\ Eric J. Gowans and Branka Grubor-Bauk* \\ Virology Laboratory, Discipline of Surgery, Basil Hetzel Institute for Translational Health Research and \\ University of Adelaide, Adelaide 5011, Australia; danushka.wijesundara@adelaide.edu.au (D.K.W.); \\ makutiro.masavuli@adelaide.edu.au (M.G.M.); zelalem.mekonnen@adelaide.edu.au (Z.A.M.); \\ eric.gowans@adelaide.edu.au (E.J.G.) \\ * Correspondence: ashish.shrestha@adelaide.edu.au (A.C.S.); branka.grubor@adelaide.edu.au (B.G.-B.); \\ Tel.: +61-8-8222-6590 (A.C.S.); +61-8-8222-7368 (B.G.-B.)
}

Received: 8 March 2019; Accepted: 25 April 2019; Published: 30 April 2019

check for updates

\begin{abstract}
DNA vaccines present one of the most cost-effective platforms to develop global vaccines, which have been tested for nearly three decades in preclinical and clinical settings with some success in the clinic. However, one of the major challenges for the development of DNA vaccines is their poor immunogenicity in humans, which has led to refinements in DNA delivery, dosage in prime/boost regimens and the inclusion of adjuvants to enhance their immunogenicity. In this review, we focus on adjuvants that can enhance the immunogenicity of DNA encoded antigens and highlight the development of a novel cytolytic DNA platform encoding a truncated mouse perforin. The application of this innovative DNA technology has considerable potential in the development of effective vaccines.
\end{abstract}

Keywords: DNA vaccine; adjuvants; vaccine delivery; plasmid; cytolytic; perforin; bicistronic; $\mathrm{HCV}$; HIV

\section{Introduction}

Vaccines represent an effective strategy in the fight against infectious diseases and recent estimates suggest that vaccination prevents 2-3 million deaths every year [1]. The need for rapid and large scale vaccine production during epidemics against emerging pathogens is a major challenge in vaccine development [2], including effective vaccines for antigenically diverse and versatile pathogens that successfully subvert host immunity such as human immunodeficiency virus (HIV), hepatitis $\mathrm{C}$ virus $(\mathrm{HCV})$, and malaria [3-5].

DNA vaccines can overcome some of these challenges, as it is relatively easy to produce large number of doses within a short period of time, and they are stable at ambient temperature and do not require cold chain transportation. They are also consistent between lots and have an excellent safety profile allowing for safety evaluations by regulatory authorities and distribution in a large scale [6,7]. Importantly, DNA vaccines can induce both humoral and cell-mediated responses in the vaccinated host [8-10]. Although they are safe and well tolerated, they are often poorly immunogenic and inefficacious in humans [11]. Therefore, recent studies on the advancements of DNA vaccines are focused on effective delivery and increasing the immunogenicity of the encoded antigen/s of interest [12,13].

Effective immunization with DNA vaccines requires efficient transfection of host cells which is highly dependent on the delivery route and use of devices. Conventional delivery routes to introduce the DNA vaccine include intramuscular, intradermal, subcutaneous and oral routes [12]. The preferred delivery route depends on the requirement to activate specific immune cells. The skin is rich in 
immune cells including local dendritic cells (DCs) and natural killer (NK) cells, and is therefore likely to be a more favorable site for vaccine delivery $[14,15]$. Attempts to improve DNA delivery have been made through other physical methods with the use of 'gene guns' or electroporation, which transiently permeabilizes the cell membrane to efficiently transfer the DNA resulting in increased vaccine uptake by skin and muscle cells [16]. Although these methods have shown to increase DNA uptake $[17,18]$, they require optimization to achieve increased efficiency and acceptance for clinical use. An alternative approach to improve transfection efficiency includes formulation of DNA with liposomes or nanoparticles [19]. Liposomal delivery can be affected by pre-systemic (epithelial) and systemic barriers (enzymatic degradation, binding, and opsonization) [20]. Encapsulation of DNA with nanoparticles has been reported to increase DNA uptake or transfection efficiency [21,22]. Some of the challenges in the use of nanoparticles with DNA include encapsulation inefficiency, endocytosis by target cells and toxicity [23].

The use of genetic adjuvants is one approach to enhance the immunogenicity of the antigen and can be used to complement other strategies (e.g., DNA delivery) also designed to improve the immunogenicity of DNA vaccines. Upon immunization with a DNA vaccine, the target cells uptake DNA by endocytosis [24] and the transfected cells express the DNA-encoded protein antigen(s). When antigen-presenting cells (APCs) are directly transfected, the intracellular proteins are processed and immunogenic epitopes are then presented by MHC Class I molecules, which can directly stimulate naïve $\mathrm{CD} 8^{+} \mathrm{T}$ cells $[12,25]$. The protein immunogen released from transfected cells can be endocytosed and/or phagocytosed by other APCs and are presented by MHC class II molecules to activate naive $\mathrm{CD}^{+} \mathrm{T}$ cells $[25,26]$. If the proteins are expressed by stromal cells like keratinocytes, APCs can also indirectly capture secreted antigens and cross-present by MHC Class I molecules to further stimulate $\mathrm{CD}^{+} \mathrm{T}$ cells [27]. After DNA vaccination, $\mathrm{CD} 8^{+} \mathrm{T}$ cells specific to the vaccine antigen undergo expansion, acquire effector functions and differentiates into memory $\mathrm{CD} 8^{+} \mathrm{T}$ cells $[28,29]$. The memory cells differentiate into effector memory $\mathrm{T}$ cells upon re-exposure to the antigen $[29,30]$. The ability of a DNA vaccine to elicit $\mathrm{T}$ cell immunity is thus dependent on activating APCs to present antigen: MHC complexes to T cells [31] and adjuvants can serve as an important costimulatory factor to enhance this process.

In this brief review, based on our experience, we discuss the progress in the development of DNA vaccines, approaches to improve delivery and genetic adjuvants used to enhance immunogenicity. We focus on an innovative cytolytic DNA technology developed and patented in our laboratory.

\section{DNA Vaccine Adjuvants}

The immunogenicity of DNA vaccines is enhanced by CpG motifs present in the plasmid backbone, which can activate APC via toll like receptors (TLR9) [32-34]. Unmethylated CpG motifs have been reported to induce $B$ cell proliferation and secretion of immunoglobulin in vitro and in vivo [33]. Activation of macrophages and DCs results in upregulation of antigen presentation and costimulatory molecules, and secretion of cytokines (IL-12 and IL-18) involved in helper T cells (Th1) response [34]. Thus, CpG motifs in DNA plasmids serve as a 'natural adjuvant' for DNA vaccines. Plasmid DNA can be designed to encode additional adjuvants with the antigen(s) of interest. Molecular adjuvants such as fusion proteins including heat shock protein 70 (HSP70), and vesicular stomatitis virus (VSVG) have been developed and used to enhance vaccine immunogenicity [35-37]. The gene encoding such proteins as adjuvants is either fused with the gene encoding the vaccine antigen to produce a fusion protein driven by a same promoter or as separate proteins driven by different promoters in the same or different plasmid. Co-encoding of genes creates a suitable cellular micro environment such as sustained antigen release and/or upregulation of cytokines, enhancing the immunogenicity of DNA vaccines [38].

A majority of the studies on experimental DNA vaccines with genetic adjuvants have been studied in animal models such as mice (Table 1), and very few of these have been clinically tested (Table 2). 
Limited published data on clinical trials pose difficulty to compare efficacy between adjuvants in animals and humans.

Table 1. Molecular adjuvants and immunogenicity of DNA vaccines in animals.

\begin{tabular}{|c|c|c|c|c|c|}
\hline Adjuvants & Antigens & Delivery & Host & Responses & Ref. \\
\hline \multicolumn{6}{|c|}{ Costimulatory molecules } \\
\hline CD80, CD86 & HIV-1 (Env, Gag, Pol) & DC, IM & Mouse Chimpanzee & $+\mathrm{CMI}$ & [39] \\
\hline CD40 LT & beta-gal & $\mathrm{DC}, \mathrm{SC}$ & Mouse & $+\mathrm{Ab},+\mathrm{CMI}$ & [40] \\
\hline ICAM-1 & HIV-1 (Env) & DC, IM & Mouse & $+\mathrm{CMI}$ & [41] \\
\hline \multicolumn{6}{|c|}{ Cytokines } \\
\hline IL- 2, IFN- $\gamma$ & HIV-1 (Env, Gag, Pol) & DC, IM & Mouse & $+\mathrm{Ab},+\mathrm{CMI}$ & [42] \\
\hline IL-6 & Influenza (HA) & DC, GG & Mouse & $+\mathrm{Ab}$ & [43] \\
\hline IL-2,12, IFN- $\gamma$ & $\mathrm{HBV}$ & DC, IM & Mouse & $+\mathrm{CMI}$ & [44] \\
\hline TNF- $\alpha$, IL-15 & HIV (Env, Gag, Pol) & DC, IM & Mouse & $+\mathrm{CMI}$ & {$[45]$} \\
\hline \multicolumn{6}{|c|}{ Toll like receptor adaptor/signaling molecules } \\
\hline TRIF & Influenza (HA), tumor E7 & $\mathrm{BC}, \mathrm{IM} / \mathrm{EP}$ & Mouse & $+\mathrm{CMI}$ & [46] \\
\hline MyD88 & Influenza (HA), tumor E7 & $\mathrm{BC}, \mathrm{IM} / \mathrm{EP}$ & Mouse & $+\mathrm{Ab}$ & [46] \\
\hline FliC & Influenza A (Np) & DC, ID & Mouse & $+\mathrm{Ab},+\mathrm{CMI}$ & [47] \\
\hline IRF $1,3,7$ & Influenza virus (HA, Np) & $\mathrm{DC} / \mathrm{BC}, \mathrm{IM}$ & Mouse & $+\mathrm{Ab},+\mathrm{CMI}$ & [48] \\
\hline TBK-1 & P. f (SE36) & DC, IM & Mouse & $+\mathrm{Ab},+\mathrm{CMI}$ & [49] \\
\hline HMGB1 & HIV-1 (Gag, Env) & $\mathrm{DC}, \mathrm{IM} / \mathrm{EP}$ & Mouse & $+\mathrm{Ab},+\mathrm{CMI}$ & [50] \\
\hline DAI & Survivin & $\mathrm{DC}, \mathrm{ID}$ & Mouse & $+\mathrm{CMI}$ & [51] \\
\hline chMDA5 & Influenza (HA) & DC, IM & Chicken & $+\mathrm{Ab}$ & [52] \\
\hline Ii & P. $\mathrm{f}(\mathrm{ME})$ & FC, IM & Mouse & $+\mathrm{CMI}$ & [53] \\
\hline \multicolumn{6}{|c|}{ Toxins/Viral proteins } \\
\hline FrC & Sc-fv & FC, IM & Mouse & $+\mathrm{Ab}$ & [54] \\
\hline DTa & HIV (Gag) & BC, ID & Mouse & -CMI & [55] \\
\hline NSP4 & HCV NS3 & $\mathrm{BC}, \mathrm{ID}$ & Mouse & $+/-\mathrm{CMI}$ & [56] \\
\hline & HIV (Gag) & DC, ID & Mouse & $+\mathrm{CMI}$ & [37] \\
\hline VSVG & NS3 & $\mathrm{BC}, \mathrm{ID}$ & Mouse & $+/-\mathrm{CMI}$ & [57] \\
\hline \multicolumn{6}{|c|}{ Heat shock proteins } \\
\hline & mucin 1 & $\mathrm{DC}$ & Mouse & $+\mathrm{CMI}$ & [58] \\
\hline Calreticulin & HPV-16 E7 & FC, GG & Mouse & $+\mathrm{CMI}$ & [59] \\
\hline HSP70 & HIV (Gag) & $\mathrm{BC}, \mathrm{ID}$ & Mouse & $+\mathrm{CMI}$ & [60] \\
\hline \multicolumn{6}{|c|}{ Complement inhibitor } \\
\hline IMX313 & HIV (Tat) & $\mathrm{FC}, \mathrm{ID}$ & Mouse & $+\mathrm{Ab},+\mathrm{CMI}$ & [36] \\
\hline \multicolumn{6}{|c|}{ Cytolytic protein } \\
\hline & HIV (Gag) & $\mathrm{BC}, \mathrm{ID}$ & Mouse & $+\mathrm{CMI}$ & [55] \\
\hline PRF & HCV (NS3) & $\mathrm{BC}, \mathrm{ID}$ & Mouse, Pig & $+\mathrm{CMI}$ & [26] \\
\hline & HCV (NS345B) & BC, ID & Mouse & $+\mathrm{CMI}$ & [57] \\
\hline
\end{tabular}

Adjuvants: LT: ligand/trimer, IL: Interleukin, TNF: Tumor necrosis factor, TRIF: Toll-interleukin-1 receptor domain-containing adaptor-inducing beta interferon, MyD88: myeloid differentiation primary response, FliC: phase-1 flagellin, IRF: Interferon regulatory factor, TBK-1: TANK-binding kinase 1, HMGB1: High-mobility group box 1 protein, DAI: DNA-dependent activator of interferon (IFN) regulatory factors, chMDA5: melanoma differentiation-associated gene 5 product, FrC: Fragment $C$ of tetanus toxin, DTa: Diphtheria toxin subunit A, NSP4: Nonstructural protein 4, li: MHC class II invariant chain, HSP: Heat shock protein, VSVG: Vesicular stomatitis virus, PRF: Perforin; Antigens: HIV: Human immunodeficiency virus, Env: Envelope, GAG: Group antigens, Pol: Reverse transcriptase, beta-gal: beta galactosidase, FMDV: Foot and Mouth Disease Virus, VP1: Virus protein 1, HBV: Hepatitis B virus, HA: Haemagglutinin, Sc-fv: Single chain fragment variable, Np: Nucleoprotein, P.f: Plasmodium falciparum, SE36: serine repeat antigen 36, HCV: Hepatitis C virus, NS3: Nonstructural protein 3, ME: Multiepitope string fused to the native P. falciparum T9/96 strain,NS345B: Nonstructural proteins 3, 4, 5B; Delivery: DC: Different constructs, BC: Bicistronic construct, FC: Fusion protein/single construct, IM: Intra muscular, SC: Subcutaneous, GG: Gene gun, EP: Electroporation, ID: Intradermal; Responses: +: Increase, -: Decrease, +/-: No significant change, CMI: T cell responses, Ab: Humoral responses; Ref.: References. 
Table 2. Molecular adjuvants tested with DNA vaccines in humans.

\begin{tabular}{|c|c|c|c|c|c|}
\hline Adjuvants & Antigens & Delivery & Responses & Trial Phase & Ref. \\
\hline IL-12, IL-15 & HIV-1 (Gag) & DC, IM & $+/-\mathrm{Ab},+/-\mathrm{CMI}$ & I & [61] \\
\hline GM-CSF, IL-2 & Her2 & RP, IM & $+\mathrm{Ab},+\mathrm{CMI}$ & $\mathrm{I}$ & [62] \\
\hline GM-CSF & CEA & RP, ID & $+\mathrm{Ab},+\mathrm{CMI}$ & I & [63] \\
\hline IL-2/Ig & HIV-1 Gag/Pol/Nef/Env & $\mathrm{BC}, \mathrm{IM}$ & $+\mathrm{Ab},+\mathrm{CMI}$ & $\mathrm{I}$ & {$[64]$} \\
\hline IL-12 & HIV (MAG-Gag, Pol, Env, Nef, Tat, Vif) & $\mathrm{DC}, \mathrm{IM} / \mathrm{EP}$ & $-\mathrm{Ab},+\mathrm{CMI}$ & I & {$[65,66]$} \\
\hline IL-12 & HIV-1 (Env, Gag, Pol) & DC, IM/EP & $+\mathrm{CMI}$ & I & [67] \\
\hline GM-CSF & PAP & RPID & $-\mathrm{Ab},+\mathrm{CMI}$ & $\mathrm{I} / \mathrm{II} \mathrm{a}$ & [68] \\
\hline HSP70 & HPV16 (E7) & FC, IM & $-\mathrm{Ab},+/-\mathrm{CMI}$ & I & [69] \\
\hline
\end{tabular}

Adjuvants: IL: Interleukin, GM-CSF: Granulocyte/macrophage colony-stimulating factor; Antigens: HIV: Human immunodeficiency virus, Gag: Group antigens, Her2: Human epidermal growth factor receptor 2, CEA: Human carcinoembryonic antigen, MAG: Multi antigen, Env: Envelope, Pol: Reverse transcriptase, Nef: N-terminally myristoylated protein, Tat: Transactivator of transcription, Vif: viral infectivity factor, PAP: Prostatic Acid Phosphatase, HSP: Heat shock protein, HPV: Human Papilloma Virus; Delivery: DC: Different constructs, BC: Bicistronic construct, FC: Fusion protein/single construct, RP: Adjuvant as recombinant protein, IM: Intramuscular, ID: Intradermal; Responses: +: Increase, -: Decrease, +/-: No significant change, Ab: Humoral responses, CMI: T cell responses; Ref.: References.

\subsection{Cytokines}

Different cytokines, such as interleukins (IL-2, IL-6, IL-12), chemokines, granulocyte/macrophage colony-stimulating factor (GM-CSF), costimulatory molecules (CD40, CD80, and CD86), and signaling molecules (Interferon regulatory factor -3 ) have been used as genetic adjuvants with DNA vaccines [39,40,42-44,48,68]. Genes expressing IFN- $\gamma$ IL-2, IL-12, IL-15, and IL-18 have been used to stimulate Th1 responses [44,45,70], and IL-4, IL-6, IL-10, IL-13, for Th2 stimulation [42,43,71-73]. The inclusion of genes encoding cytokines, like IL-2 or IL-12, as adjuvants for HIV-1 DNA vaccines is known to increase cell mediated immunity (CMI) [74,75]. However, a bicistronic HIV DNA encoding gp120 and IL-2 elicited weaker specific immune response than monocistronic HIV-1 gp120 DNA [76]. Combinations of genetic adjuvants like IL-2 and IL-15 with HIV-1 DNA vaccine have also been used but no synergistic effect on the level of total antibody to HIV-1 antigen was reported [77]. A phase I/Ila trial showed that coadministration of DNA vaccine encoding prostatic acid phosphatase (PAP) with GM-CSF elicited PAP-specific $\mathrm{CD}^{+}$and/or $\mathrm{CD}^{+} \mathrm{T}$ cell responses [68]. However, GM-CSF was administered as a recombinant protein.

\subsection{Heat Shock Proteins}

HSP70, a class of molecular chaperone, is known to induce maturation of DCs and activation of the Th1 pathway [78-80]. A fusion vaccine for multiple myeloma termed hDKK1-hHSP70 was shown to be effective in inhibiting the targeted tumor and increased survival of vaccinated mice by eliciting tumor-specific humoral and cellular immune responses [80]. However, a DNA vaccine encoding HPV16E7 fused with HSP70, targeting HPV16 and cervical intraepithelial neoplasia 2/3 failed to enhance significant $T$ cell responses in a Phase I clinical trial [69]. A bicistronic DNA encoding HSP70 as a membrane bound or secreted protein has been used to improve the immunogenicity of a HIV Gag [60]. In this case, HSP70 expression was driven by a weaker SV40 promoter and HIV Gag by a stronger CMV promoter. Such a vaccine design enhanced Gag-specific $\mathrm{T}$ cell responses, providing greater protection in mice challenged with EcoHIV [60]. EcoHIV is a chimeric virus containing the envelope protein gp 80 of mouse leukemia virus rather than HIV gp 120 that can replicate in mouse leukocytes in vivo, thus representing a viable mouse challenge model for early assessment of HIV vaccines [81]. The proposed mechanism of HSP70 as an adjuvant is that TLR 2/4 on DCs interacts with secreted or bound HSP70, further attracting DCs to the site of antigen expression. This is followed by DC maturation, presentation of antigens by MHC molecules and secretion of cytokines and costimulatory molecules [82], thus enhancing $\mathrm{T}$ cell immune responses against the vaccine antigen. 


\subsection{Chicken Complement Inhibitor}

A chimeric version of the oligomerization domain from the chicken complement inhibitor (C4bp) was used to produce an oligomeric form of vaccine antigens $[35,83]$. This protein, termed IMX313, forms a heptameric structure of the vaccine protein. This has been used to develop DNA vaccines for tuberculosis, malaria and HIV to enhance humoral and/or cellular responses [35,36,84]. Vaccination with a DNA vaccine encoding secreted HIV Tat (TPA-Tat IMX313) induced higher humoral and cellular responses and improved protection against EcoHIV challenge in mice [36]. A phase I clinical trial of tuberculosis vaccine MVA85A-IMX313 evaluated the vaccine to be safe and immunogenic, but cellular (Ag85A-specific IFN- Y) and humoral (MVA-specific IgG) responses were not significant [85]. Thus, the ability of such an adjuvant to enhance immunogenicity of DNA vaccines in humans is still debated.

\subsection{Viral Fusion Protein}

VSV G is a type III viral fusion envelope protein, which mediates fusion of the virus envelope and the host cell membrane [86]. The use of fusogenic membrane glycoprotein (FMG) gene from VSV in a DNA vaccine encoding the $\mathrm{H} 7$ protein of human papillomavirus type 16 was shown to enhance $\mathrm{CD}^{+} \mathrm{T}$ cell responses and effectively control growth of tumors [87]. The VSV G protein was also shown to induce a T-response at low doses or a T-independent response at higher doses [88]. FMG fuses cells into large multinucleated syncytia, which are then killed by a nonapoptotic mechanism [89]. Syncytiosomes are released from the membrane and present antigens efficiently to DCs [90]. FMGs can thus act as an adjuvant for any antigen expressed by a DNA vaccine. Vaccination of mice with the hepatitis $\mathrm{C}$ virus (HCV) nonstructural protein 3 (NS3) together with VSVG resulted in increased frequency of IFN- $\gamma$, but not TNF- $\alpha$ - or IL-2-producing CD3+ CD44+ CD8+ effector memory T ( $\left.\mathrm{T}_{\mathrm{EM}}\right)$ cells [57]. This DNA vaccine was constructed in a bicistronic vector with VSVG co-encoded in the same plasmid with HCV NS3. VSVG expression was driven by a weaker SV40 promoter and NS3 by a stronger CMV promoter [57]. However, others have also reported an increase in the specific CMI when the immunogen and VSVG were expressed from different plasmids [37,87].

\subsection{Cytolytic Protein}

Perforin (PRF) is a pore forming protein released by immune cells including NK cells and cytotoxic T lymphocytes (CTL) [91]. The 67-kilodalton PRF protein oligomerizes to form pores that serve as a channel to release granzyme into the cytosol of target cells [92]. Suicide genes inducing apoptosis of target cells have been used for cancer therapies, and the role of apoptotic cell death in vaccination, whether immune-stimulatory or immune-suppressive, is debated [93]. Recently, a novel DNA technology has been developed-termed cytolytic DNA technology-in which a truncated mouse PRF is incorporated in a bicistronic DNA vector to act as a vaccine adjuvant $[55-57,94]$.

\section{Cytolytic DNA Vaccines}

Cytolytic DNA vaccines are based on a bicistronic DNA plasmid constructed on a pVax backbone (Invitrogen) with a Cytomegalovirus (CMV) promoter and a Simian Virus (SV40) promoter [55]. The gene encoding the protein of interest as an immunogen is inserted downstream of the CMV promoter and the gene encoding a truncated version of mouse PRF downstream of the SV40 promoter (Figure 1). The SV40 is a weaker promoter compared to CMV and has been shown to result in 10-fold lower protein expression in transfected HEK293T cells in vitro $[55,95]$.

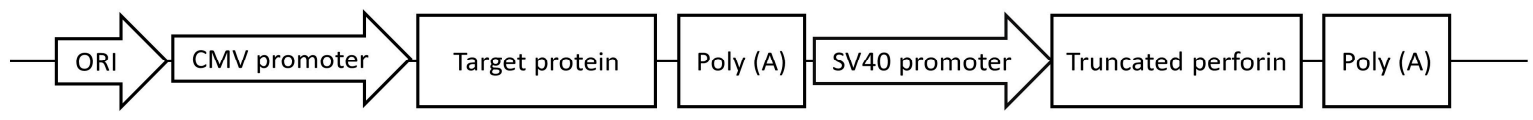

Figure 1. Schematic diagram of cytolytic bicistronic DNA plasmid (rDNA-PRF) with two different promoters and encoding protein of interest (immunogen) and truncated perforin. 
The PRF gene was modified to express a truncated version of PRF ( $60 \mathrm{KDa})$ lacking the final 12 amino acid residues of the $C$ terminus (unstructured region of PRF) $[56,57,94]$ in order for PRF to become cytolytic [96]. The final $12 \mathrm{C}$-terminal amino acids are required to export PRF protein from the endoplasmic reticulum (ER) to the Golgi, from where glycosylated PRF is then transported to secretory granules [96]. Removal of the C-terminal abrogates the export of PRF from the ER and its subsequent accumulation in the ER is cytotoxic to the host cell $[96,97]$.

\subsection{Mechanism}

Different recombinant cytolytic DNA-PRF vaccines (rDNA-PRF) have been shown to elicit immune responses higher than those elicited by canonical DNA vaccines (without PRF) and the mechanism underlying this has been established [94]. A previous study showed that coexpression of HCV NS3 and PRF elicited nonapoptotic cell death in transfected cells, whilst immunization with NS3-PRF DNA vaccine increased NS3-specific T cell mediated responses as evidenced by increased NS3-specific IFN- $\gamma$ responses in an ELISpot assay and increased numbers of polyfunctional CD8 ${ }^{+} \mathrm{T}_{\mathrm{EM}}$ cells that simultaneously secreted IFN- $\gamma$, IL-2, and TNF- $\alpha$ [56]. Cytolytic DNA platform where the expression of immunogen is driven by a stronger promoter allows for sufficient antigen expression and accumulation within the target cells followed by nonapoptotic cell death due to lesser expression of PRF driven by a weaker SV40 promoter; thus, balancing the level of antigen expression with the timing of cell death [94].

Necrosis is considered as the mechanism of cell death by PRF as evidenced by release of lactate dehydrogenase (LDH) and low caspase activity $[55,56,94]$. LDH release occurs after the rupture of cell membrane during secondary necrosis $[98,99]$. In contrast, LDH was not released by cells treated with doxorubicin (a proapoptotic drug) or cells transfected with NS3 wild type PRF or NS3 12del483A PRF (mutant and nontoxic PRF) [94]. Expression of PRF from a cytolytic DNA, e.g., NS3 PRF vaccine, thus results in necrotic cell death mediated by receptor-interacting protein-1 kinase activity, as evidenced by detection of uncleaved cytokeratin 18 in Huh-7 cells [56]. Necrosis releases damage associated molecular patterns (DAMPs) which in turn activate DCs to migrate to the site of vaccination $[100,101]$.

When purified DCs including the CD8 $\alpha^{+}$subset from naive C57BL/6 mice were exposed to HEK293T cells (transfected with Ovalbumin-PRF), it resulted in upregulation of costimulatory molecules (CD80/CD86), indicating maturation of the immune cells with the cytolytic DNA [94]. A significant increase in $\mathrm{CD} 11 \mathrm{c}^{+} \mathrm{DC}$ s and cross-presenting $\mathrm{CD} 8 \mathrm{a}^{+} \mathrm{DCs}$, and upregulation of $\mathrm{CD} 80$ has been reported in mice vaccinated with a cytolytic DNA HIV 1 Gag PRF compared to a canonical DNA vaccine [55]. Local and migrated DCs at the site of inflammation can take up antigens by endocytosis and are also exposed to DAMPs. Activated and matured DCs can then prime naïve $\mathrm{CD} 8^{+} \mathrm{T}$ cells (Figure 2). Antigen cross-presentation by DCs to $\mathrm{CD} 8^{+} \mathrm{T}$ cells has been shown to increase the number of proliferating $\mathrm{CD} 8^{+}$ T cells by $\sim 2$-fold with cytolytic DNA compared to the noncytolytic PRF DNA [94]. Thus, a cytolytic DNA vaccine has an inbuilt adjuvant to enhance the immunogenicity of the vaccine immunogen. Whereas, the immunogenicity of canonical DNA vaccines mostly depends on direct transfection of DCs and to a lesser extent cross-presentation of antigens shed from transfected cells and/or derived from transfected cells that have undergone spontaneous cell death [94].

Several studies have established that DCs exposed to necrotic or lytic cells expressing antigens mature and cross-present more efficiently than DCs exposed to antigens derived from a cellular milieu that comprise of apoptotic cells [102-106]. Comparative studies evaluating the ability of proapoptotic (e.g., rotavirus nonstructural protein 4 (NSP4) and diphtheria toxin subunit A (DTa)) and necrotic proteins (e.g., truncated PRF) to enhance the immunogenicity of DNA when encoded in plasmid DNA vaccines showed that truncated PRF is the most effective for this purpose [55-57]. However, a caveat is that vaccine-encoded antigens need to accumulate significantly inside the cell before necrosis occurs following expression of truncated PRF in order to activate DCs to cross-present vaccine-encoded antigens $[55,94]$. 


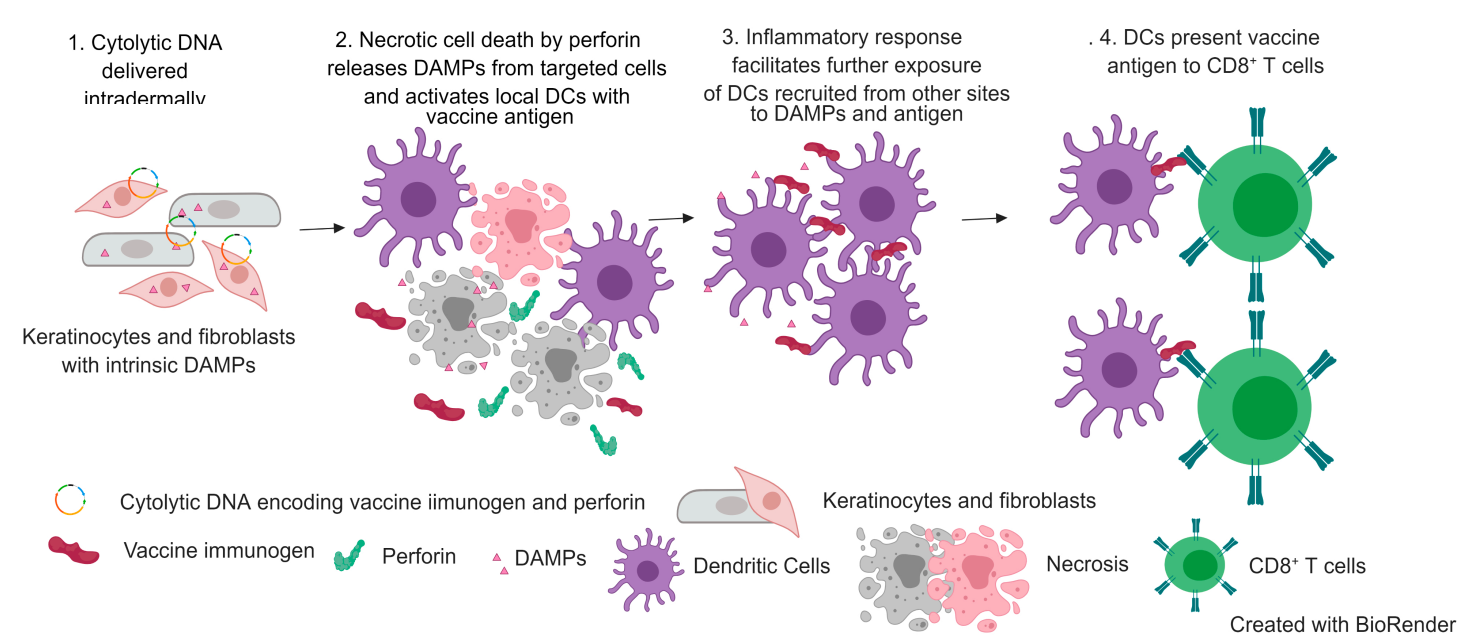

Figure 2. Mechanism of rDNA-PRF immunogenicity.

\subsection{Cytolytic HIV and HCV DNA Vaccines}

rDNA-PRF technology has been used in the development of HIV and HCV DNA vaccines $[55,57,107]$. Direct comparison of the effects of the cytolytic PRF and the apoptotic protein DTa on the immunogenicity of the HIV-1 Gag protein showed that PRF activated DCs more efficiently, as evidenced by the increase in frequency of cross-presenting DCs and upregulation of activation marker (CD80) [55]. In both DNA vaccines, PRF and DTa were driven by SV40 promoter. Immunization of mice with a DNA vaccine encoding proapoptotic DTa as an adjuvant in a HIV Gag DTa vaccine resulted in decreased DC activation, suggesting that DTa-induced apoptosis attenuated immune response [55]. Furthermore, improved protection in the mouse EcoHIV challenge model was achieved with rDNA-PRF encoding HIV Gag compared to protection levels in mice vaccinated with a canonical Gag DNA vaccine [57]. A rDNA-PRF vaccine encoding the HCV NS3 protein coexpressed with PRF was shown to increase NS3-specific CMI in mice and pigs, compared to NS3 coexpression with a proapoptotic protein, the rotavirus NSP4 protein [56]. NSP4 is an enterotoxin that elicits a proapoptotic effect by disrupting the mitochondrial membrane and activating caspase-3, -8 , and $-9[108,109]$. This study showed that PRF coexpression induced cell death by necrosis, and thus enhanced NS3-specific immune responses, whereas, proapoptotic NSP4 reduced NS3-specific response [56]. Importantly, HCV NS3 PRF was more immunogenic than the canonical NS3 vaccine in pigs, demonstrating the translational potential of the cytolytic DNA vaccines in human clinical trials [56]. Likewise, we have shown that a multi-antigenic HCV DNA vaccine encoding genotype 3a proteins NS3, NS4A, NS4B, and NS5B coexpressed with PRF induced robust CMI against the range of HCV NS proteins, compared to coexpression with VSVG [57]. We also showed that multi-antigenic and multigenotypic (HCV genotype 1 and 3a) DNA cocktail vaccines encoding PRF can significantly increase the magnitude and breadth of CMI responses to NS3 and NS5B against both genotypes compared to those elicited by a single-genotype vaccine [107].

\section{Conclusions}

DNA vaccines are still a promising option in the development of novel vaccination strategies. Although they have many advantages, the ability to induce effective immune responses in humans required for protection has been challenging. These challenges include ineffective delivery and poor uptake of DNA. Consequently, a recent focus has been in the development of delivery methods and/or inclusion of genetic adjuvants. Such genetic adjuvants are generally coexpressed with the antigen of interest or delivered through different plasmids. In the quest to develop and identify effective genetic adjuvants, a range of adjuvants was tested (HSP70, VSVG, IMX313, DTa, and PRF) and a novel and promising cytolytic DNA vaccine strategy has been developed. This cytolytic DNA vaccine is unique as it is based on a bicistronic plasmid with the ability to coexpress antigen and PRF in a balanced 
mechanism causing necrosis of vaccine-transduced cells, followed by increased activation of immune cells and cross presentation of vaccine immunogen. Cytolytic DNA vaccines encoding nonstructural proteins of HCV have been tested to enhance immunogenicity of vaccine antigen in mice [57,107] and in a large preclinical animal model, the pig [56]. Likewise, increased immunogenicity and improved protection against EcoHIV challenge in mice with HIV Gag PRF [60] demonstrate the effectiveness of cytolytic DNA vaccines.

Adjuvants that provide effective costimulation for immune responses with specific immunogens may not have a similar effect with other immunogens, and therefore these need to be tested for their efficacy. Use of a genetic adjuvant such as PRF produces a suitable microenvironment for multiple/different immunogens and thus improves the delivery, immunogenicity and effectiveness of DNA vaccines. This strategy has considerable potential in the development of DNA-based vaccines against a range of infectious agents.

Author Contributions: Writing-concept and original draft preparation: A.C.S.; concept, review, and editing: B.G.-B., E.J.G., and D.K.W.; section contributions and review: M.G.M. and Z.A.M.

Funding: Cytolytic DNA vaccines developed in our laboratory and reviewed in this manuscript have been supported by the grants received from the National Health and Medical Research Council, Australian Centre for HIV and Hepatitis Virology Research, the National Foundation for Medical Research and Innovation, and The Hospital Research Foundation (THRF).

Acknowledgments: We thank THRF and the donor community for supporting the development of our novel DNA vaccines. Ashish C. Shrestha and Danushka K. Wijesundara are recipients of Early Career Fellowships from THRF.

Conflicts of Interest: The authors declare no conflict of interest.

\section{References}

1. World Health Organisation. 10 Facts on Immunization. Available online: https://www.who.int/features/ factfiles/immunization/en/ (accessed on 20 December 2018).

2. Plotkin, S.; Robinson, J.M.; Cunningham, G.; Iqbal, R.; Larsen, S. The complexity and cost of vaccine manufacturing-An overview. Vaccine 2017, 35, 4064-4071. [CrossRef]

3. Li, S.; Plebanski, M.; Smooker, P.; Gowans, E.J. Editorial: Why Vaccines to HIV, HCV, and Malaria Have So Far Failed-Challenges to Developing Vaccines Against Immunoregulating Pathogens. Front. Microbiol. 2015, 6, 1318. [CrossRef]

4. Wilhelm, J. HIV, Tuberculosis, and Malaria. Available online: https://www.sabin.org/sites/sabin.org/files/ wilhelm_v2.pdf (accessed on 19 February 2019).

5. Rappuoli, R.; Aderem, A. A 2020 vision for vaccines against HIV, tuberculosis and malaria. Nature 2011, 473, 463-469. [CrossRef] [PubMed]

6. Whalen, R.G. DNA vaccines for emerging infectious diseases: What if? Emerg. Infect. Dis. 1996, 2, $168-175$. [CrossRef] [PubMed]

7. Suschak, J.J.; Williams, J.A.; Schmaljohn, C.S. Advancements in DNA vaccine vectors, non-mechanical delivery methods, and molecular adjuvants to increase immunogenicity. Hum. Vaccin. Immunother. 2017, 13, 2837-2848. [CrossRef] [PubMed]

8. Seok, H.; Noh, J.Y.; Lee, D.Y.; Kim, S.J.; Song, C.S.; Kim, Y.C. Effective humoral immune response from a H1N1 DNA vaccine delivered to the skin by microneedles coated with PLGA-based cationic nanoparticles. J. Controlled Release 2017, 265, 66-74. [CrossRef]

9. Hurtado-Melgoza, M.L.; Ramos-Ligonio, A.; Álvarez-Rodríguez, L.M.; Meza-Menchaca, T.; López-Monteon, A. Differential humoral and cellular immunity induced by vaccination using plasmid DNA and protein recombinant expressing the NS3 protein of dengue virus type 3. J. Biomed. Sci. 2016, $23,85$. [CrossRef]

10. Maslow, J.N. Vaccines for emerging infectious diseases: Lessons from MERS coronavirus and Zika virus. Hum. Vaccin. Immunother. 2017, 13, 2918-2930. [CrossRef]

11. Ferraro, B.; Morrow, M.P.; Hutnick, N.A.; Shin, T.H.; Lucke, C.E.; Weiner, D.B. Clinical applications of DNA vaccines: Current progress. Clin. Infect. Dis. 2011, 53, 296-302. [CrossRef] 
12. Hobernik, D.; Bros, M. DNA Vaccines-How Far From Clinical Use? Int. J. Mol. Sci. 2018, 19. [CrossRef]

13. Wahren, B.; Liu, M.A. DNA Vaccines: Recent Developments and the Future. Vaccines 2014, 2, 785-796. [CrossRef]

14. Kenney, R.T.; Frech, S.A.; Muenz, L.R.; Villar, C.P.; Glenn, G.M. Dose sparing with intradermal injection of influenza vaccine. N. Engl. J. Med. 2004, 351, 2295-2301. [CrossRef]

15. Fehres, C.; Garcia-Vallejo, J.J.; Unger, W.; Van Kooyk, Y. Skin-Resident Antigen-Presenting Cells: Instruction Manual for Vaccine Development. Front. Immunol. 2013, 4, 157. [CrossRef] [PubMed]

16. Gothelf, A.; Gehl, J. What you always needed to know about electroporation based DNA vaccines. Hum. Vaccin. Immunother. 2012, 8, 1694-1702. [CrossRef]

17. Aihara, H.; Miyazaki, J. Gene transfer into muscle by electroporation in vivo. Nat. biotechnol. 1998, 16, 867-870. [CrossRef] [PubMed]

18. Young, J.L.; Dean, D.A. Electroporation-mediated gene delivery. Adv. Genet. 2015, 89, 49-88. [CrossRef]

19. Schwendener, R.A. Liposomes as vaccine delivery systems: A review of the recent advances. Ther. Adv. Vaccines 2014, 2, 159-182. [CrossRef] [PubMed]

20. Saffari, M.; Moghimi, H.R.; Dass, C.R. Barriers to Liposomal Gene Delivery: from Application Site to the Target. Iran. J. Pharm. Res. 2016, 15, 3-17.

21. Gvili, J.; Machluf, M. 544. PLGA Nanoparticles for DNA Vaccination-Waiving Complexity and Increasing Efficiency. Mol. Ther. 2006, 13, S209. [CrossRef]

22. Penumarthi, A.; Parashar, D.; Abraham, A.N.; Dekiwadia, C.; Macreadie, I.; Shukla, R.; Smooker, P.M. Solid lipid nanoparticles mediate non-viral delivery of plasmid DNA to dendritic cells. J. Nanoparticle Res. 2017, 19, 210. [CrossRef]

23. Chen, J.; Guo, Z.; Tian, H.; Chen, X. Production and clinical development of nanoparticles for gene delivery. Mol. Ther. Methods. Clin. Dev. 2016, 3, 16023. [CrossRef]

24. Seternes, T.; Tonheim, T.C.; Løvoll, M.; Bøgwald, J.; Dalmo, R.A. Specific endocytosis and degradation of naked DNA in the endocardial cells of cod (Gadus morhua L.). J. Exp. Biol. 2007, 210, 2091. [CrossRef]

25. Elnekave, M.; Furmanov, K.; Nudel, I.; Arizon, M.; Clausen, B.E.; Hovav, A.-H. Directly Transfected Langerin ${ }^{+}$Dermal Dendritic Cells Potentiate $\mathrm{CD}^{+}$; T Cell Responses following Intradermal Plasmid DNA Immunization. J. Immunol. 2010, 185, 3463. [CrossRef]

26. Greenland, J.R.; Letvin, N.L. Chemical adjuvants for plasmid DNA vaccines. Vaccine 2007, 25, 3731-3741. [CrossRef]

27. Coban, C.; Kobiyama, K.; Jounai, N.; Tozuka, M.; Ishii, K.J. DNA vaccines. Hum. Vaccin. Immunother. 2013, 9 , 2216-2221. [CrossRef]

28. Badovinac, V.P.; Harty, J.T. Programming, demarcating, and manipulating CD8+ T-cell memory. Immunol. Rev. 2006, 211, 67-80. [CrossRef]

29. Hovav, A.-H.; Panas, M.W.; Rahman, S.; Sircar, P.; Gillard, G.; Cayabyab, M.J.; Letvin, N.L. Duration of Antigen Expression In Vivo following DNA Immunization Modifies the Magnitude, Contraction, and Secondary Responses of CD8 ${ }^{+}$T Lymphocytes. J. Immunol. 2007, 179, 6725. [CrossRef]

30. Jabbari, A.; Harty, J.T. Secondary memory $\mathrm{CD}^{+} \mathrm{T}$ cells are more protective but slower to acquire a central-memory phenotype. J. Exp. Med. 2006, 203, 919. [CrossRef]

31. Mahanty, S.; Prigent, A.; Garraud, O. Immunogenicity of infectious pathogens and vaccine antigens. BMC Immunol. 2015, 16, 31. [CrossRef]

32. Ahmad-Nejad, P.; Häcker, H.; Rutz, M.; Bauer, S.; Vabulas, R.M.; Wagner, H. Bacterial CpG-DNA and lipopolysaccharides activate Toll-like receptors at distinct cellular compartments. Eur. J. Immunol. 2002, 32, 1958-1968. [CrossRef]

33. Krieg, A.M.; Yi, A.-K.; Matson, S.; Waldschmidt, T.J.; Bishop, G.A.; Teasdale, R.; Koretzky, G.A.; Klinman, D.M. CpG motifs in bacterial DNA trigger direct B-cell activation. Nature 1995, 374, 546. [CrossRef]

34. Dalpke, A.; Zimmermann, S.; Heeg, K. CpG-Oligonucleotides in Vaccination: Signaling and Mechanisms of Action. Immunobiology 2001, 204, 667-676. [CrossRef]

35. Li, Y.; Leneghan, D.B.; Miura, K.; Nikolaeva, D.; Brian, I.J.; Dicks, M.D.; Fyfe, A.J.; Zakutansky, S.E.; de Cassan, S.; Long, C.A.; et al. Enhancing immunogenicity and transmission-blocking activity of malaria vaccines by fusing Pfs25 to IMX313 multimerization technology. Sci. Rep. 2016, 6, 18848. [CrossRef] 
36. Tomusange, K.; Wijesundara, D.; Gummow, J.; Garrod, T.; Li, Y.; Gray, L.; Churchill, M.; Grubor-Bauk, B.; Gowans, E.J. A HIV-Tat/C4-binding protein chimera encoded by a DNA vaccine is highly immunogenic and contains acute EcoHIV infection in mice. Sci. Rep. 2016, 6, 29131. [CrossRef]

37. Marsac, D.; Loirat, D.; Petit, C.; Schwartz, O.; Michel, M.L. Enhanced Presentation of Major Histocompatibility Complex Class I-Restricted Human Immunodeficiency Virus Type 1 (HIV-1) Gag-Specific Epitopes after DNA Immunization with Vectors Coding for Vesicular Stomatitis Virus Glycoprotein-Pseudotyped HIV-1 Gag Particles. J. Virol. 2002, 76, 7544. [CrossRef]

38. Awate, S.; Babiuk, L.A.; Mutwiri, G. Mechanisms of action of adjuvants. Front. Immunol. 2013, 4, 114. [CrossRef]

39. Kim, J.J.; Nottingham, L.K.; Wilson, D.M.; Bagarazzi, M.L.; Tsai, A.; Morrison, L.D.; Javadian, A.; Chalian, A.A.; Agadjanyan, M.G.; Weiner, D.B. Engineering DNA vaccines via co-delivery of co-stimulatory molecule genes. Vaccine 1998, 16, 1828-1835. [CrossRef]

40. Yang, B.; Jeang, J.; Yang, A.; Wu, T.C.; Hung, C.F. DNA vaccine for cancer immunotherapy. Hum. Vaccin. Immunother. 2014, 10, 3153-3164. [CrossRef]

41. Kim, J.J.; Tsai, A.; Nottingham, L.K.; Morrison, L.; Cunning, D.M.; Oh, J.; Lee, D.J.; Dang, K.; Dentchev, T.; Chalian, A.A.; et al. Intracellular adhesion molecule-1 modulates beta-chemokines and directly costimulates T cells in vivo. J. Clin. Invest. 1999, 103, 869-877. [CrossRef]

42. Kim, J.J.; Yang, J.S.; Montaner, L.; Lee, D.J.; Chalian, A.A.; Weiner, D.B. Coimmunization with IFN-gamma or IL-2, but not IL-13 or IL-4 cDNA can enhance Th1-type DNA vaccine-induced immune responses in vivo. J. Interferon Cytokine Res. 2000, 20, 311-319. [CrossRef]

43. Larsen, D.L.; Dybdahl-Sissoko, N.; McGregor, M.W.; Drape, R.; Neumann, V.; Swain, W.F.; Lunn, D.P.; Olsen, C.W. Coadministration of DNA encoding interleukin-6 and hemagglutinin confers protection from influenza virus challenge in mice. J. Virol. 1998, 72, 1704-1708.

44. Chow, Y.H.; Chiang, B.L.; Lee, Y.L.; Chi, W.K.; Lin, W.C.; Chen, Y.T.; Tao, M.H. Development of Th1 and Th2 populations and the nature of immune responses to hepatitis B virus DNA vaccines can be modulated by codelivery of various cytokine genes. J. Immunol. 1998, 160, 1320-1329.

45. Kim, J.J.; Trivedi, N.N.; Nottingham, L.K.; Morrison, L.; Tsai, A.; Hu, Y.; Mahalingam, S.; Dang, K.; Ahn, L.; Doyle, N.K.; et al. Modulation of amplitude and direction of in vivo immune responses by co-administration of cytokine gene expression cassettes with DNA immunogens. Eur. J. Immunol. 1998, 28, 1089-1103. [CrossRef]

46. Takeshita, F.; Tanaka, T.; Matsuda, T.; Tozuka, M.; Kobiyama, K.; Saha, S.; Matsui, K.; Ishii, K.J.; Coban, C.; Akira, S.; et al. Toll-like receptor adaptor molecules enhance DNA-raised adaptive immune responses against influenza and tumors through activation of innate immunity. J. Virol. 2006, 80, 6218-6224. [CrossRef]

47. Applequist, S.E.; Rollman, E.; Wareing, M.D.; Liden, M.; Rozell, B.; Hinkula, J.; Ljunggren, H.G. Activation of innate immunity, inflammation, and potentiation of DNA vaccination through mammalian expression of the TLR5 agonist flagellin. J. Immunol. 2005, 175, 3882-3891. [CrossRef]

48. Sasaki, S.; Amara, R.R.; Yeow, W.-S.; Pitha, P.M.; Robinson, H.L. Regulation of DNA-raised immune responses by cotransfected interferon regulatory factors. J. Virol. 2002, 76, 6652-6659. [CrossRef]

49. Coban, C.; Kobiyama, K.; Aoshi, T.; Takeshita, F.; Horii, T.; Akira, S.; Ishii, K.J. Novel strategies to improve DNA vaccine immunogenicity. Curr. Gene Ther. 2011, 11, 479-484. [CrossRef]

50. Muthumani, G.; Laddy, D.J.; Sundaram, S.G.; Fagone, P.; Shedlock, D.J.; Kannan, S.; Wu, L.; Chung, C.W.; Lankaraman, K.M.; Burns, J.; et al. Co-immunization with an optimized plasmid-encoded immune stimulatory interleukin, high-mobility group box 1 protein, results in enhanced interferon-gamma secretion by antigen-specific CD8 T cells. Immunology 2009, 128, e612-e620. [CrossRef]

51. Lladser, A.; Mougiakakos, D.; Tufvesson, H.; Ligtenberg, M.A.; Quest, A.F.; Kiessling, R.; Ljungberg, K. DAI (DLM-1/ZBP1) as a genetic adjuvant for DNA vaccines that promotes effective antitumor CTL immunity. Mol. Ther. 2011, 19, 594-601. [CrossRef]

52. Liniger, M.; Summerfield, A.; Ruggli, N. MDA5 can be exploited as efficacious genetic adjuvant for DNA vaccination against lethal H5N1 influenza virus infection in chickens. PLoS ONE 2012, 7, e49952. [CrossRef]

53. Halbroth, B.R.; Sebastian, S.; Poyntz, H.C.; Bregu, M.; Cottingham, M.G.; Hill, A.V.S.; Spencer, A.J. Development of a Molecular Adjuvant to Enhance Antigen-Specific CD8(+) T Cell Responses. Sci. Rep. 2018, 8, 15020. [CrossRef] 
54. King, C.A.; Spellerberg, M.B.; Zhu, D.; Rice, J.; Sahota, S.S.; Thompsett, A.R.; Hamblin, T.J.; Radl, J.; Stevenson, F.K. DNA vaccines with single-chain Fv fused to fragment $C$ of tetanus toxin induce protective immunity against lymphoma and myeloma. Nat. Med. 1998, 4, 1281-1286. [CrossRef]

55. Gargett, T.; Grubor-Bauk, B.; Garrod, T.; Yu, W.; Miller, D.; Major, L.; Wesselingh, S.; Suhrbier, A.; Gowans, E. Induction of antigen-positive cell death by the expression of Perforin, but not DTa, from a DNA vaccine enhances the immune respons. Immunol. Cell Biol. 2014, 92, 359-367. [CrossRef]

56. Grubor-Bauk, B.; Yu, W.; Wijesundara, D.; Gummow, J.; Garrod, T.; Brennan, A.J.; Voskoboinik, I.; Gowans, E.J. Intradermal delivery of DNA encoding HCV NS3 and perforin elicits robust cell-mediated immunity in mice and pigs. Gene Ther. 2016, 23, 26-37. [CrossRef]

57. Gummow, J.; Li, Y.; Yu, W.; Garrod, T.; Wijesundara, D.; Brennan, A.J.; Mullick, R.; Voskoboinik, I.; Grubor-Bauk, B.; Gowans, E.J. A Multiantigenic DNA Vaccine That Induces Broad Hepatitis C Virus-Specific T-Cell Responses in Mice. J. Viro.l 2015, 89, 7991-8002. [CrossRef]

58. Wang, J.; Gao, Z.P.; Qin, S.; Liu, C.B.; Zou, L.L. Calreticulin is an effective immunologic adjuvant to tumor-associated antigens. Exp. Ther. Med. 2017, 14, 3399-3406. [CrossRef]

59. Peng, S.; Ji, H.; Trimble, C.; He, L.; Tsai, Y.-C.; Yeatermeyer, J.; Boyd, D.A.K.; Hung, C.-F.; Wu, T.C. Development of a DNA Vaccine Targeting Human Papillomavirus Type 16 Oncoprotein E6. J. Virol. 2004, 78, 8468. [CrossRef]

60. Garrod, T.J.; Grubor-Bauk, B.; Gargett, T.; Li, Y.; Miller, D.S.; Yu, W.; Major, L.; Burrell, C.J.; Wesselingh, S.; Suhrbier, A.; et al. DNA vaccines encoding membrane-bound or secreted forms of heat shock protein 70 exhibit improved potency. Eur. J. Immunol. 2014, 44, 1992-2002. [CrossRef]

61. Kalams, S.A.; Parker, S.; Jin, X.; Elizaga, M.; Metch, B.; Wang, M.; Hural, J.; Lubeck, M.; Eldridge, J.; Cardinali, M.; et al. Safety and immunogenicity of an HIV-1 gag DNA vaccine with or without IL-12 and/or IL-15 plasmid cytokine adjuvant in healthy, HIV-1 uninfected adults. PLoS ONE 2012, 7, e29231. [CrossRef]

62. Norell, H.; Poschke, I.; Charo, J.; Wei, W.Z.; Erskine, C.; Piechocki, M.P.; Knutson, K.L.; Bergh, J.; Lidbrink, E.; Kiessling, R. Vaccination with a plasmid DNA encoding HER-2/neu together with low doses of GM-CSF and IL-2 in patients with metastatic breast carcinoma: a pilot clinical trial. J. Transl. Med. 2010, 8, 53. [CrossRef]

63. Staff, C.; Mozaffari, F.; Haller, B.K.; Wahren, B.; Liljefors, M. A Phase I safety study of plasmid DNA immunization targeting carcinoembryonic antigen in colorectal cancer patients. Vaccine 2011, 29, 6817-6822. [CrossRef]

64. Baden, L.R.; Blattner, W.A.; Morgan, C.; Huang, Y.; Defawe, O.D.; Sobieszczyk, M.E.; Kochar, N.; Tomaras, G.D.; McElrath, M.J.; Russell, N.; et al. Timing of plasmid cytokine (IL-2/Ig) administration affects HIV-1 vaccine immunogenicity in HIV-seronegative subjects. J. Infect. Dis. 2011, 204, 1541-1549. [CrossRef]

65. Elizaga, M.L.; Li, S.S.; Kochar, N.K.; Wilson, G.J.; Allen, M.A.; Tieu, H.V.N.; Frank, I.; Sobieszczyk, M.E.; Cohen, K.W.; Sanchez, B.; et al. Safety and tolerability of HIV-1 multiantigen pDNA vaccine given with IL-12 plasmid DNA via electroporation, boosted with a recombinant vesicular stomatitis virus HIV Gag vaccine in healthy volunteers in a randomized, controlled clinical trial. PLoS ONE 2018, 13, e0202753. [CrossRef]

66. Li, S.S.; Kochar, N.K.; Elizaga, M.; Hay, C.M.; Wilson, G.J.; Cohen, K.W.; De Rosa, S.C.; Xu, R.; Ota-Setlik, A.; Morris, D.; et al. DNA Priming Increases Frequency of T-Cell Responses to a Vesicular Stomatitis Virus HIV Vaccine with Specific Enhancement of CD8+ T-Cell Responses by Interleukin-12 Plasmid DNA. Clin. Vaccin. Immunol. 2017, 24. [CrossRef]

67. Kalams, S.A.; Parker, S.D.; Elizaga, M.; Metch, B.; Edupuganti, S.; Hural, J.; De Rosa, S.; Carter, D.K.; Rybczyk, K.; Frank, I.; et al. Safety and comparative immunogenicity of an HIV-1 DNA vaccine in combination with plasmid interleukin 12 and impact of intramuscular electroporation for delivery. J. Infect. Dis. 2013, 208, 818-829. [CrossRef]

68. McNeel, D.G.; Dunphy, E.J.; Davies, J.G.; Frye, T.P.; Johnson, L.E.; Staab, M.J.; Horvath, D.L.; Straus, J.; Alberti, D.; Marnocha, R.; et al. Safety and Immunological Efficacy of a DNA Vaccine Encoding Prostatic Acid Phosphatase in Patients With Stage D0 Prostate Cancer. J. Clin. Oncol. 2009, 27, 4047-4054. [CrossRef]

69. Trimble, C.L.; Peng, S.; Kos, F.; Gravitt, P.; Viscidi, R.; Sugar, E.; Pardoll, D.; Wu, T.C. A phase I trial of a human papillomavirus DNA vaccine for HPV16+ cervical intraepithelial neoplasia 2/3. Clin. Cancer Res. 2009, 15, 361-367. [CrossRef] 
70. Kim, J.J.; Nottingham, L.K.; Tsai, A.; Lee, D.J.; Maguire, H.C.; Oh, J.; Dentchev, T.; Manson, K.H.; Wyand, M.S.; Agadjanyan, M.G.; et al. Antigen-specific humoral and cellular immune responses can be modulated in rhesus macaques through the use of IFN-gamma, IL-12, or IL-18 gene adjuvants. J. Med. Primatol. 1999, 28, 214-223. [CrossRef]

71. Scheerlinck, J.-P.Y. Genetic adjuvants for DNA vaccines. Vaccine 2001, 19, 2647-2656. [CrossRef]

72. Okada, E.; Sasaki, S.; Ishii, N.; Aoki, I.; Yasuda, T.; Nishioka, K.; Fukushima, J.; Miyazaki, J.; Wahren, B.; Okuda, K. Intranasal immunization of a DNA vaccine with IL-12- and granulocyte-macrophage colony-stimulating factor (GM-CSF)-expressing plasmids in liposomes induces strong mucosal and cell-mediated immune responses against HIV-1 antigens. J. immunol. 1997, 159, 3638-3647.

73. Kim, J.J.; Simbiri, K.A.; Sin, J.I.; Dang, K.; Oh, J.; Dentchev, T.; Lee, D.; Nottingham, L.K.; Chalian, A.A.; McCallus, D.; et al. Cytokine molecular adjuvants modulate immune responses induced by DNA vaccine constructs for HIV-1 and SIV. J. Interferon Cytokine Res. 1999, 19, 77-84. [CrossRef]

74. Xin, K.Q.; Hamajima, K.; Sasaki, S.; Honsho, A.; Tsuji, T.; Ishii, N.; Cao, X.R.; Lu, Y.; Fukushima, J.; Shapshak, P.; et al. Intranasal administration of human immunodeficiency virus type-1 (HIV-1) DNA vaccine with interleukin-2 expression plasmid enhances cell-mediated immunity against HIV-1. Immunology 1998, 94, 438-444. [CrossRef]

75. Tsuji, T.; Hamajima, K.; Fukushima, J.; Xin, K.Q.; Ishii, N.; Aoki, I.; Ishigatsubo, Y.; Tani, K.; Kawamoto, S.; Nitta, Y.; et al. Enhancement of cell-mediated immunity against HIV-1 induced by coinnoculation of plasmid-encoded HIV-1 antigen with plasmid expressing IL-12. J. Immunol. 1997, 158, 4008-4013.

76. Barouch, D.H.; Santra, S.; Steenbeke, T.D.; Zheng, X.X.; Perry, H.C.; Davies, M.E.; Freed, D.C.; Craiu, A.; Strom, T.B.; Shiver, J.W.; et al. Augmentation and suppression of immune responses to an HIV-1 DNA vaccine by plasmid cytokine/Ig administration. J. Immunol. 1998, 161, 1875-1882.

77. Xin, K.Q.; Hamajima, K.; Sasaki, S.; Tsuji, T.; Watabe, S.; Okada, E.; Okuda, K. IL-15 expression plasmid enhances cell-mediated immunity induced by an HIV-1 DNA vaccine. Vaccine 1999, 17, 858-866. [CrossRef]

78. Wang, L.; Rollins, L.; Gu, Q.; Chen, S.Y.; Huang, X.F. A Mage3/Heat Shock Protein70 DNA vaccine induces both innate and adaptive immune responses for the antitumor activity. Vaccine 2009, 28, 561-570. [CrossRef]

79. Feder, M.E.; Hofmann, G.E. Heat-shock proteins, molecular chaperones, and the stress response: evolutionary and ecological physiology. Annu. Rev. Physiol. 1999, 61, 243-282. [CrossRef]

80. Liu, T.-T.; Wu, Y.; Niu, T. Human DKK1 and human HSP70 fusion DNA vaccine induces an effective anti-tumor efficacy in murine multiple myeloma. Oncotarget 2017, 9, 178-191. [CrossRef]

81. Potash, M.J.; Chao, W.; Bentsman, G.; Paris, N.; Saini, M.; Nitkiewicz, J.; Belem, P.; Sharer, L.; Brooks, A.I.; Volsky, D.J. A mouse model for study of systemic HIV-1 infection, antiviral immune responses, and neuroinvasiveness. Proc. Natl. Acad. Sci. USA 2005, 102, 3760-3765. [CrossRef]

82. Garrod, T.; Grubor-Bauk, B.; Yu, S.; Gargett, T.; Gowans, E.J. Encoded novel forms of HSP70 or a cytolytic protein increase DNA vaccine potency. Hum. Vaccin. Immunother. 2014, 10, 2679-2683. [CrossRef]

83. Spencer, A.J.; Hill, F.; Honeycutt, J.D.; Cottingham, M.G.; Bregu, M.; Rollier, C.S.; Furze, J.; Draper, S.J.; Sogaard, K.C.; Gilbert, S.C.; et al. Fusion of the Mycobacterium tuberculosis antigen 85A to an oligomerization domain enhances its immunogenicity in both mice and non-human primates. PLoS ONE 2012, 7, e33555. [CrossRef]

84. Ogun, S.A.; Dumon-Seignovert, L.; Marchand, J.B.; Holder, A.A.; Hill, F. The oligomerization domain of C4-binding protein ( $\mathrm{C} 4 \mathrm{bp})$ acts as an adjuvant, and the fusion protein comprised of the 19-kilodalton merozoite surface protein 1 fused with the murine $\mathrm{C} 4 \mathrm{bp}$ domain protects mice against malaria. Infect. Immun. 2008, 76, 3817-3823. [CrossRef]

85. Minhinnick, A.; Satti, I.; Harris, S.; Wilkie, M.; Sheehan, S.; Stockdale, L.; Manjaly Thomas, Z.R.; Lopez-Ramon, R.; Poulton, I.; Lawrie, A.; et al. A first-in-human phase 1 trial to evaluate the safety and immunogenicity of the candidate tuberculosis vaccine MVA85A-IMX313, administered to BCG-vaccinated adults. Vaccine 2016, 34, 1412-1421. [CrossRef]

86. Ci, Y.; Yang, Y.; Xu, C.; Shi, L. Vesicular stomatitis virus G protein transmembrane region is crucial for the hemi-fusion to full fusion transition. Sci Rep 2018, 8, 10669. [CrossRef]

87. Mao, C.-P.; Hung, C.-F.; Kang, T.H.; He, L.; Tsai, Y.-C.; Wu, C.-Y.; Wu, T.C. Combined administration with DNA encoding vesicular stomatitis virus G protein enhances DNA vaccine potency. J. Virol. 2010, 84, 2331-2339. [CrossRef] 
88. Freer, G.; Burkhart, C.; Ciernik, I.; Bachmann, M.F.; Hengartner, H.; Zinkernagel, R.M. Vesicular stomatitis virus Indiana glycoprotein as a T-cell-dependent and -independent antigen. J. Virol. 1994, 68, 3650.

89. Bateman, A.; Bullough, F.; Murphy, S.; Emiliusen, L.; Lavillette, D.; Cosset, F.-L.; Cattaneo, R.; Russell, S.J.; Vile, R.G. Fusogenic Membrane Glycoproteins As a Novel Class of Genes for the Local and Immune-mediated Control of Tumor Growth. Cancer Res. 2000, 60, 1492.

90. Bateman, A.R.; Harrington, K.J.; Kottke, T.; Ahmed, A.; Melcher, A.A.; Gough, M.J.; Linardakis, E.; Riddle, D.; Dietz, A.; Lohse, C.M.; et al. Viral Fusogenic Membrane Glycoproteins Kill Solid Tumor Cells by Nonapoptotic Mechanisms That Promote Cross Presentation of Tumor Antigens by Dendritic Cells. Cancer Res. 2002, 62, 6566.

91. Chiang, S.C.C.; Theorell, J.; Entesarian, M.; Meeths, M.; Mastafa, M.; Al-Herz, W.; Frisk, P.; Gilmour, K.C.; Ifversen, M.; Langenskiöld, C.; et al. Comparison of primary human cytotoxic T-cell and natural killer cell responses reveal similar molecular requirements for lytic granule exocytosis but differences in cytokine production. Blood 2013, 121, 1345. [CrossRef]

92. Law, R.H.; Lukoyanova, N.; Voskoboinik, I.; Caradoc-Davies, T.T.; Baran, K.; Dunstone, M.A.; D'Angelo, M.E.; Orlova, E.V.; Coulibaly, F.; Verschoor, S.; et al. The structural basis for membrane binding and pore formation by lymphocyte perforin. Nature 2010, 468, 447-451. [CrossRef]

93. Leitner, W.W.; Restifo, N.P. DNA vaccines and apoptosis: to kill or not to kill? J. Clin. Investig. 2003, 112, 22-24. [CrossRef]

94. Wijesundara, D.K.; Yu, W.; Quah, B.J.C.; Eldi, P.; Hayball, J.D.; Diener, K.R.; Voskoboinik, I.; Gowans, E.J.; Grubor-Bauk, B. Cytolytic DNA vaccine encoding lytic perforin augments the maturation of- and antigen presentation by- dendritic cells in a time-dependent manner. Sci. Rep. 2017, 7, 8530. [CrossRef]

95. Qin, J.Y.; Zhang, L.; Clift, K.L.; Hulur, I.; Xiang, A.P.; Ren, B.-Z.; Lahn, B.T. Systematic comparison of constitutive promoters and the doxycycline-inducible promoter. PLoS ONE 2010, 5, e10611. [CrossRef]

96. Brennan, A.J.; Chia, J.; Browne, K.A.; Ciccone, A.; Ellis, S.; Lopez, J.A.; Susanto, O.; Verschoor, S.; Yagita, H.; Whisstock, J.C.; et al. Protection from endogenous perforin: Glycans and the $\mathrm{C}$ terminus regulate exocytic trafficking in cytotoxic lymphocytes. Immunity 2011, 34, 879-892. [CrossRef]

97. Lopez, J.A.; Susanto, O.; Jenkins, M.R.; Lukoyanova, N.; Sutton, V.R.; Law, R.H.; Johnston, A.; Bird, C.H.; Bird, P.I.; Whisstock, J.C.; et al. Perforin forms transient pores on the target cell plasma membrane to facilitate rapid access of granzymes during killer cell attack. Blood 2013, 121, 2659-2668. [CrossRef]

98. Zhan, Y.; van de Water, B.; Wang, Y.; Stevens, J.L. The roles of caspase-3 and bcl-2 in chemically-induced apoptosis but not necrosis of renal epithelial cells. Oncogene 1999, 18, 6505. [CrossRef]

99. Fink, S.L.; Cookson, B.T. Apoptosis, pyroptosis, and necrosis: mechanistic description of dead and dying eukaryotic cells. Infect. Immun. 2005, 73, 1907-1916. [CrossRef]

100. Matzinger, P. Tolerance, danger, and the extended family. Annu. Rev. Immunol. 1994, 12, 991-1045. [CrossRef]

101. Kono, H.; Rock, K.L. How dying cells alert the immune system to danger. Nat. Rev. Immunol. 2008, 8, 279-289. [CrossRef]

102. Melcher, A.; Todryk, S.; Hardwick, N.; Ford, M.; Jacobson, M.; Vile, R.G. Tumor immunogenicity is determined by the mechanism of cell death via induction of heat shock protein expression. Nat. Med. 1998, 4, 581-587. [CrossRef]

103. Gallucci, S.; Lolkema, M.; Matzinger, P. Natural adjuvants: endogenous activators of dendritic cells. Nat. Med. 1999, 5, 1249-1255. [CrossRef] [PubMed]

104. Sauter, B.; Albert, M.L.; Francisco, L.; Larsson, M.; Somersan, S.; Bhardwaj, N. Consequences of cell death: exposure to necrotic tumor cells, but not primary tissue cells or apoptotic cells, induces the maturation of immunostimulatory dendritic cells. J. Exp. Med. 2000, 191, 423-434. [CrossRef] [PubMed]

105. Basu, S.; Binder, R.J.; Suto, R.; Anderson, K.M.; Srivastava, P.K. Necrotic but not apoptotic cell death releases heat shock proteins, which deliver a partial maturation signal to dendritic cells and activate the NF-kappa B pathway. Int. Immunol. 2000, 12, 1539-1546. [CrossRef] [PubMed]

106. Joffre, O.P.; Segura, E.; Savina, A.; Amigorena, S. Cross-presentation by dendritic cells. Nat. Rev. Immunol. 2012, 12, 557-569. [CrossRef]

107. Wijesundara, D.K.; Gummow, J.; Li, Y.; Yu, W.; Quah, B.J.; Ranasinghe, C.; Torresi, J.; Gowans, E.J.; Grubor-Bauk, B. Induction of Genotype Cross-Reactive, Hepatitis C Virus-Specific, Cell-Mediated Immunity in DNA-Vaccinated Mice. J. Virol. 2018, 92, e02133-17. [CrossRef] [PubMed] 
108. Bhowmick, R.; Halder, U.C.; Chattopadhyay, S.; Chanda, S.; Nandi, S.; Bagchi, P.; Nayak, M.K.; Chakrabarti, O.; Kobayashi, N.; Chawla-Sarkar, M. Rotaviral enterotoxin nonstructural protein 4 targets mitochondria for activation of apoptosis during infection. J. Biol. Chem. 2012, 287, 35004-35020. [CrossRef]

109. Ma, Z.; Wang, Y.; Zhao, H.; Xu, A.T.; Wang, Y.; Tang, J.; Feng, W.H. Porcine reproductive and respiratory syndrome virus nonstructural protein 4 induces apoptosis dependent on its 3C-like serine protease activity. PLoS ONE 2013, 8, e69387. [CrossRef]

C 2019 by the authors. Licensee MDPI, Basel, Switzerland. This article is an open access article distributed under the terms and conditions of the Creative Commons Attribution (CC BY) license (http://creativecommons.org/licenses/by/4.0/). 